\title{
Tomato ringspot virus Coat Protein Binds to ARGONAUTE 1 and Suppresses the Translation Repression of a Reporter Gene
}

\author{
Rajita A. Karran and Hélène Sanfaçon \\ Pacific Agri-Food Research Centre, Agriculture and Agri-Food Canada, 4200 Highway 97, Summerland, B.C., VoH 1Z0, \\ Canada
}

Submitted 4 April 2014. Accepted 30 April 2014.

\begin{abstract}
RNA silencing regulates plant gene expression and antiviral defenses and functions by cleaving target RNAs or repressing translation. As a counter defense, many plant viruses encode suppressor proteins that sequester small RNAs or inactivate Argonaute (AGO) proteins. All known plant virus silencing suppressor activities eventually inhibit the degradation of target mRNAs. Using a transiently expressed green fluorescent protein (GFP) reporter gene, we show that Tomato ringspot virus (ToRSV) coat protein (CP) is a suppressor of RNA silencing that enhances GFP expression but does not prevent the degradation of the GFP mRNA or the accumulation of GFP small interfering RNAs (siRNAs). Coexpression of the $\mathrm{CP}$ with GFP resulted in increased association of residual GFP mRNAs with polysome fractions and reduced association of GFP siRNAs with monosome fractions. AGO1 was co-immunoprecipitated with the CP and CP expression destabilized AGO1. A WG motif within the CP was critical for the enhanced GFP expression, AGO1 interaction, and AGO1 destabilization, suggesting that the ToRSV CP acts as an AGO-hook protein and competes for AGO binding with a plant cellular GW/WG protein involved in translation repression.
\end{abstract}

RNA silencing is a sequence-specific process that serves two main functions in eukaryotes: regulation of gene expression and defense against pathogens (Alvarado and Scholthof 2009; Brodersen and Voinnet 2006; Csorba et al. 2009; KatiyarAgarwal and Jin 2010; Parent et al. 2012). RNA silencing starts with the processing of double-stranded RNAs (dsRNAs) or self-folded hairpin structures into small RNAs (sRNAs) by RNase III-type Dicer enzymes (Ghildiyal and Zamore 2009; Krol et al. 2010). sRNAs are classified according to their origin. Small interfering RNAs (siRNAs) are derived from dsRNAs and microRNAs (miRNAs) are derived from endogenous, imperfect stem-loop precursor RNAs (Rogers and Chen 2013; Voinnet 2009). One of the two sRNA strands is incorporated into the RNA-induced silencing complex (RISC), which contains one of the highly conserved ARGONAUTE (AGO) proteins, and guides the RISC to the complementary target RNA (Czech and Hannon 2011; Ender and Meister 2010; Hutvagner and Simard 2008; Vaucheret 2008). At the post-transcriptional

Corresponding author: H. Sanfacon; Telephone: +1.250 .494 .6393 ; E-mail: helene.sanfacon@agr.gc.ca

(C) 2014 Her Majesty the Queen in Right of Canada, as represented by the Minister of Agriculture and Agri-Food Canada level, gene expression is inhibited by mRNA cleavage or translation repression. Until recently, it was believed that animal miRNAs function predominantly by repressing translation, whereas plant miRNAs mostly act through RNA slicing (Huntzinger and Izaurralde 2011). However, recent reports suggest that mRNA translation repression directed by miRNAs occurs in Arabidopsis thaliana and also show that translation repression can be genetically uncoupled from miRNA-mediated mRNA cleavage (Brodersen et al. 2008; Iwakawa and Tomari 2013; Lanet et al. 2009; Li et al. 2013; Yang et al. 2012). Plant siRNAs with perfect or near-perfect sequence identity to target mRNAs have also been shown to mediate translation repression in addition to RNA slicing (Brodersen et al. 2008). Thus, although RNA slicing is a well-recognized antiviral silencing mechanism in plants (Carbonell et al. 2012; Omarov et al. 2007; Pantaleo et al. 2007; Schuck et al. 2013), translation repression may also function against plant viral RNAs.

Although some AGO proteins slice target RNAs owing to their C-terminal RNaseH-like domain (PIWI domain) (Ender and Meister 2010), translation repression in animal cells requires association of AGO proteins with proteins containing glycine-tryptophan $(\mathrm{GW} / \mathrm{WG})$ motifs, such as members of the GW182 family (Pfaff and Meister 2013; Tritschler et al. 2010). These proteins interact directly with AGOs through their GW/WG motifs but can also repress translation in the absence of sRNA binding when they are tethered directly to mRNA, indicating that $\mathrm{GW}$ proteins rather than AGO proteins are the effectors of the translation repression (Braun et al. 2011; ElShami et al. 2007; Lazzaretti et al. 2009; Till et al. 2007). In plants, AGO1, AGO2, AGO4, AGO7, and AGO10 have RNA slicing activity (Baumberger and Baulcombe 2005; Carbonell et al. 2012; Ji et al. 2011; Qi et al. 2006; Zhu et al. 2011). AGO1 and AGO10 have also been implicated in translation repression (Brodersen et al. 2008; Lanet et al. 2009). Using a plant in vitro system, AtAGO1 was shown to mediate both miRNA-directed mRNA cleavage and miRNA-directed translation repression (Iwakawa and Tomari 2013). Although plant cells apparently lack orthologs of GW182 (Huntzinger and Izaurralde 2011), the A. thaliana SUO protein (a large protein with two C-terminal GW motifs) is required for miRNAdirected translation repression and may serve as a functional analog of the GW182 proteins (Yang et al. 2012).

Many plant viruses encode suppressors of RNA silencing (VSR) that disrupt various steps of the silencing pathway (Burgyan and Havelda 2011; Pumplin and Voinnet 2013). Among well-characterized VSR, some (e.g., the tombusvirus p19 protein) sequester sRNAs, thereby preventing their loading into the RISC (Vargason et al. 2003; Ye et al. 2003). Other 
VSR interact with or inactivate AGO1. The cucumovirus 2b protein inhibits the AGO1 slicing activity (Zhang et al. 2006). The polerovirus P0 and potexvirus P25 proteins destabilize AGO1 (Bortolamiol et al. 2007; Chiu et al. 2010; Csorba et al. 2010; Derrien et al. 2012). Some VSR, including the carmovirus p38 and ipomovirus P1 proteins, contain WG/GW motifs that mimic AGO1-interacting cellular proteins (Azevedo et al. 2010; Giner et al. 2010; Schott et al. 2012).

Tomato ringspot virus (ToRSV) is a member of the genus Nepovirus, family Secoviridae (Sanfacon et al. 2011). Nepovirus infection is typically associated with symptom recovery at late stages of infection, a phenomenon often associated with the induction of antiviral RNA silencing and viral RNA clearance (Ratcliff et al. 1997). In contrast, symptom recovery from ToRSV infection is not concomitant with viral RNA clearance, even though it is associated with accumulation of viral siRNAs (Ghoshal and Sanfacon 2014; Jovel et al. 2007). In ToRSVinfected Nicotiana benthamiana plants, symptom recovery is temperature dependent. At a higher temperature $\left(27^{\circ} \mathrm{C}\right)$, recov ery is associated with reduced translation of RNA2 (Ghoshal and Sanfacon 2014). Neither recovery nor the reduction of RNA2 translation were observed in plants silenced for AGO1, suggesting that AGO1 plays a direct or indirect role in a trans lation repression mechanism targeting ToRSV (Ghoshal and Sanfacon 2014). At a lower temperature $\left(21^{\circ} \mathrm{C}\right)$, recovery does not occur and the RNA2 is actively translated until late stages of infection (Ghoshal and Sanfacon 2014). Whether ToRSV encodes a VSR that counteracts silencing mechanisms under certain conditions (e.g., lower temperatures) or whether the temperature-dependent symptom recovery is mostly due to the previously reported increased activity of RNA silencing mecha nisms at higher temperatures (Szittya et al. 2003; Zhang et al. 2012) is not known. Systemic silencing of a green fluorescent protein (GFP) transgene was hindered in ToRSV-infected plants, suggesting that it may encode a VSR (Jovel et al. 2007). Because the coat proteins (CP) of two viruses in the family Secoviridae (Cowpea mosaic virus [CPMV], genus Comovirus, and Apple latent spherical virus, genus Cheravirus) have been shown to suppress RNA silencing (Canizares et al. 2004; Liu et al. 2004; Yaegashi et al. 2007), we have examined the silenc ing suppression activity of the ToRSV CP. We found that the ToRSV $\mathrm{CP}$ enhances the steady-state levels of the GFP protein and interacts with AGO1 in a manner dependent on a WG motif. We provide evidence that the ToRSV CP does not pre vent GFP mRNA degradation but, instead, relieves a transla tion repression mechanism active against the residual GFP mRNAs.

\section{RESULTS}

\section{Identification of a putative AGO-binding WG motif in the ToRSV CP.}

The crystal structure of nepovirus particles has been eluci dated for two species: Tobacco ringspot virus (TRSV) and Grapevine fanleaf virus (GFLV) (Chandrasekar and Johnson 1998; Schellenberger et al. 2011). In addition, cryo-electron microscopy analyses have allowed modeling of the structure of two additional nepoviruses, Blackcurrent reversion virus (BRV) and Arabis mosaic virus (ArMV) (Lai-Kee-Him et al. 2013; Seitsonen et al. 2008). These studies reveal highly conserved structural features of the nepovirus $\mathrm{CP}$. The nepovirus single $\mathrm{CP}$ consists of three jelly-roll domains. The N-terminal two jellyroll domains (B and $\mathrm{C}$ ) are equivalent to the two domains contained in the large $\mathrm{CP}$ of CPMV while the C-terminal jelly-roll domain (A) corresponds to the single domain in the small CP of CPMV (Fig. 1A). Each domain is folded in an eight-stranded $\beta$ barrel structure, with loops linking the $\beta$-barrels. Sequence alignments have allowed the prediction of similar structural features in the $\mathrm{CP}$ of other nepoviruses, including ToRSV (Chandrasekar and Johnson 1998; Seitsonen et al. 2008). Thus, the approximate location of $\beta$-barrels and loops in the ToRSV $\mathrm{CP}$ can be inferred with a reasonable degree of confidence.

The CPMV small CP is a VSR (Liu et al. 2004). Exposed amino acids present in a cleavable $\mathrm{C}$-terminal extension of the small $\mathrm{CP}$ are essential for the silencing suppression activity (Canizares et al. 2004). A similar cleavable C-terminal extension of variable length is present in some but not all nepovirus CP (Seitsonen et al. 2008) (Fig. 1A). The ToRSV CP contains a particularly large C-terminal extension (Fig. 1E).

The Agos prediction program (Karlowski et al. 2010; Zielezinski and Karlowski 2011) identified a single WG motif between the $\beta-\mathrm{D}$ and $\beta-\mathrm{E}$ barrels in the $\mathrm{A}$ domain of the ToRSV CP (Fig. 1A and B). Although this motif was not strongly predicted by the program due to its low compositional compatibility with other characterized GW/WG AGO-binding domains, it is conserved among ToRSV isolates (Fig. 1B). The $\mathrm{W}$ is also conserved in many nepoviruses but is not found in the CPMV sequence (Fig. 1B). This W is located at the C-terminus of the $\beta$-D barrel in the TRSV, GFLV, ArMV, and BRV sequences (Fig. 1B) and, although it would be accessible for interactions with other proteins in the unassembled $\mathrm{CP}$ subunit (Fig. 1C), it is not predicted to be exposed to the surface of assembled virus particles because it would be located at the interface of the A domains in the fivefold axis (Fig. 1D).

\section{Enhanced accumulation of GFP protein \\ in transient expression assays by coexpression of wild-type ToRSV CP but not \\ of a mutated CP derivative lacking the WG motif.}

To examine the silencing suppression activity of the ToRSV $\mathrm{CP}$, we used a transient expression assay and the reporter GFP gene. Accumulation of GFP-specific siRNAs in plants that expressed only GFP confirmed the induction of RNA silencing (Fig. 2B). As previously reported (Voinnet et al. 2003), coexpression of the tombusvirus p19 protein enhanced the steadystate levels of GFP protein and GFP mRNAs and reduced the accumulation of GFP siRNAs (Fig. 2A and B). This confirmed that 19 suppressed GFP silencing in our assay conditions by preventing the cleavage of the GFP mRNAs. Coexpression of wild-type (WT) ToRSV CP also enhanced the steady-state levels of GFP protein (Fig. 2A). However, the ToRSV CP did not prevent mRNA cleavage because the levels of GFP mRNAs in the presence or in the absence of $\mathrm{CP}$ were similar (Fig. 2B). The levels of GFP siRNAs were also not affected by the ToRSV CP (Fig. 2B). Coexpression of GFP with a truncated $\mathrm{CP}$ mutant missing the $\mathrm{C}$-terminal 51 amino acids (CPA) (Fig. $1 \mathrm{E}$, underlined amino acids) resulted in enhanced accumulation of GFP protein that was similar to that observed for the WT CP (Fig. 2A). As observed for the WT CP, the levels of GFP mRNAs and of GFP siRNAs were not altered (Fig. 2B). These results suggested that the C-terminal domain of the ToRSV CP is not essential for the increased accumulation of GFP. In contrast, coexpression of GFP with a $\mathrm{CP}^{\mathrm{AG}}$ mutant, in which the WG motif was mutated to AG, did not result in increased accumulation of GFP protein (Fig. 2A). Expression levels of $\mathrm{CP}^{\mathrm{AG}}$ were similar to those observed for the WT CP (Fig. 2A). This confirmed that the mutation did not alter the stability of the CP. Taken together, these results indicate that the ToRSV CP enhances the accumulation of GFP in transient expression assays but does not suppress GFP silencing through a canonical mechanism that would prevent degradation of the GFP mRNAs. Rather, the CP acts either by enhancing the translation of GFP mRNAs or by preventing the degradation of the GFP protein. We also show that the WG motif is important for this function. 


\section{Increased rate of GFP translation in presence} of the ToRSV CP.

To determine whether the ToRSV CP can alter the stability of GFP, we measured the steady-state levels of GFP after incu- bation with cycloheximide, an inhibitor of cellular translation. The rate of degradation of GFP after cycloheximide treatment was similar in leaves that expressed only GFP or in leaves that coexpressed GFP with WT or mutated CP (Fig. 3A and B).
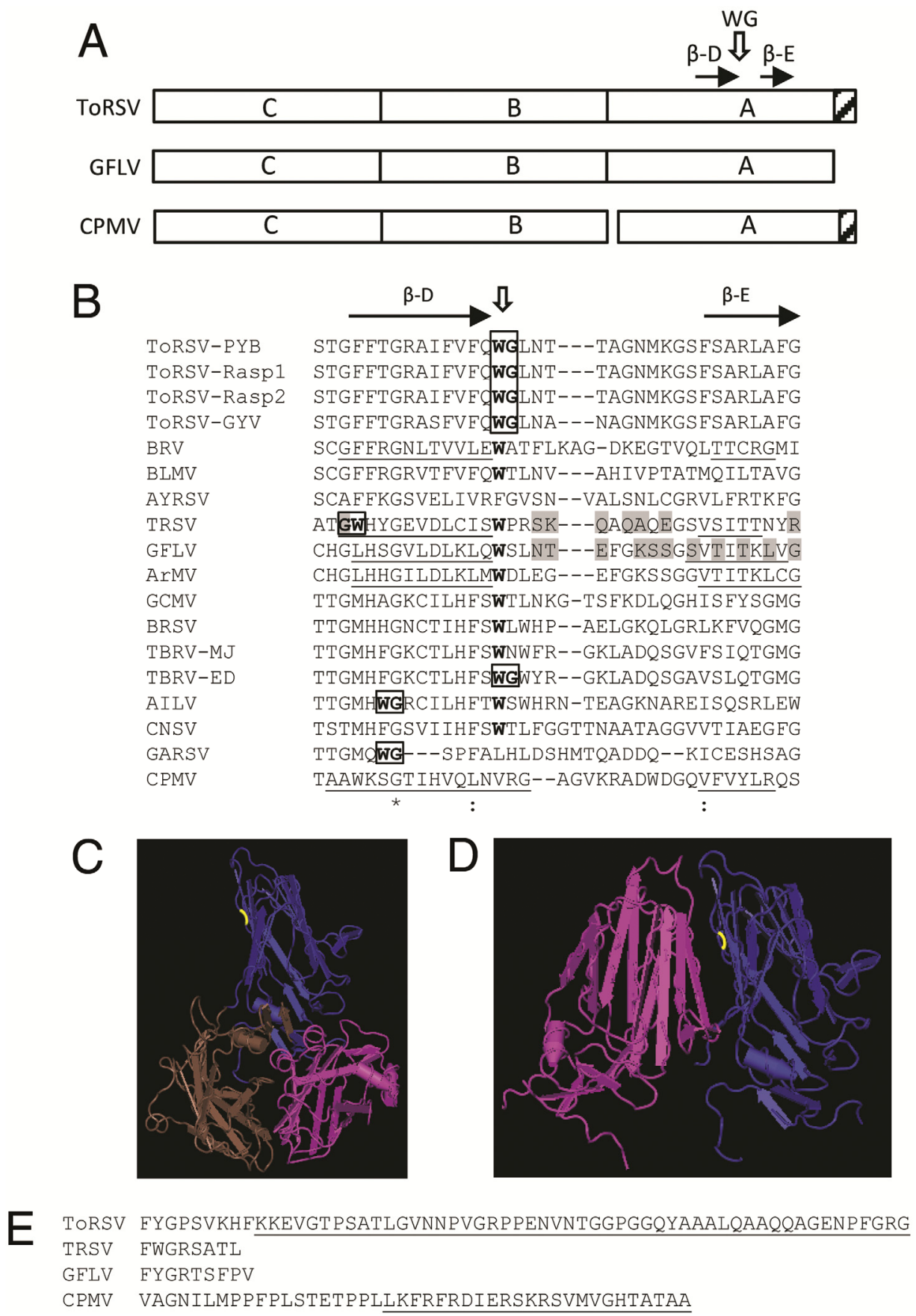

Fig. 1. WG motif and cleavable C-terminal extension in Tomato ringspot virus (ToRSV) coat protein (CP) compared with other nepo- and comoviruses. A, Schematic representation of the single nepovirus CP (ToRSV and Grapevine fanleaf virus [GFLV]) and the two comovirus CP (Cowpea mosaic virus [CPMV]). The three domains (A, B, and C) of the nepovirus $\mathrm{CP}$ are shown. The large CPMV CP contains the $\mathrm{B}$ and $\mathrm{C}$ domains, while the small $\mathrm{CP}$ contains the A domain. A cleavable C-terminal extension present in CPMV and ToRSV is shown by the hashed box. The $\beta$-D and $\beta$-E barrels in the A domain are depicted by the horizontal arrows, and the position of the WG motif in the ToRSV A domain is shown. B, Sequence alignment of the region around the ToRSV CP WG motif. GW or WG motifs are boxed. Tryptophan residues that align with the ToRSV GW motif are shown in bold and with the vertical arrow over the alignment. Amino acids composing the $\beta$-D and $\beta$-E barrels are underlined in viruses for which the structure has been determined. Amino acids known to be exposed to the surface of the virus particles in the Tobacco ringspot virus (TRSV) and GFLV structures are shaded in gray. BrV $=$ Blackcurrent reversion virus, $\mathrm{BLMV}=$ Blueberry leaf mottle virus, $\mathrm{AYRSV}=$ Artichoke yellow ringspot virus, ArMV = Arabis mosaic virus, GCMV $=$ Grapevine chrome mosaic virus, $\mathrm{TBRV}=$ Tomato black ring virus, $\mathrm{AILV}=$ Artichoke Italian latent virus, $\mathrm{CNSV}=$ Cycas necrotic stunt virus, and GARSV $=$ Grapevine Anatolian ringspot virus. C, Ribbon model of the CP subunit from GFLV with the tryptophan corresponding to the ToRSV WG motif highlighted in yellow (and shown with the arrow). Domains A, B. and C are shown in blue, brown, and pink, respectively. D, Model showing the interaction between two A domains at the fivefold axis of GFLV virus particles, with the tryptophan corresponding to the ToRSV WG motif highlighted in yellow. E, Sequence alignment showing the C-terminal extension present in ToRSV and CPMV but not in TRSV or GFLV. For CPMV, the underlined sequence corresponds to the amino acids that are cleaved off during the course of infection. For ToRSV, the underlined sequence corresponds to amino acids that are deleted in the CP $\Delta$ mutant. 
The p19 protein, used as a control, also did not affect the rate of degradation of GFP. These results indicate that the ToRSV CP does not affect the stability of GFP.

Next, we labeled nascent proteins with $\left[\mathrm{S}^{35}\right]$-methionine in planta to test whether the translation rate of GFP was enhanced in the presence of the ToRSV CP. Immunoprecipitation with GFP antibodies followed by autoradiography allowed detecting the newly translated GFP proteins. As expected, the rate of translation was enhanced in the presence of p19 (Fig. 3C), probably because of increased mRNA accumulation (Fig. 2B). The rate of GFP synthesis was also higher in leaves that coexpressed CP or CP $\Delta$ than in leaves that expressed only GFP or that coexpressed the $\mathrm{CP}^{\mathrm{AG}}$ mutant (Fig. 3C). This was not due to a reduced intake of the label, because labeling of host proteins was similar in all tested samples (Fig. 3C, unbound fractions). Taken together, these results suggest that the ToRSV CP increases the rate of translation of GFP mRNAs in a manner dependent on the presence of the WG motif.

\section{Increased association of GFP mRNAs}

with polysomes and reduced association of GFP siRNAs with monosomes in presence of ToRSV CP.

To further study the effect of $\mathrm{CP}$ on the translatability of GFP mRNAs, we conducted ribosome profiling experiments. The general translation profiles were unaffected by the $\mathrm{CP}$ because the monosome and polysome peaks were similar in the presence or absence of CP (Fig. 4A, absorbance graph). Probing for GFP mRNA distribution in each fraction revealed a shift of GFP mRNAs toward the polysome fractions in the presence of CP (Fig. 4A). Association of GFP mRNAs with monosome fractions in samples that did not express $\mathrm{CP}$ or that expressed the $\mathrm{CP}^{\mathrm{AG}}$ mutant (Fig. 4A) suggested that the translation of GFP is stalled at the elongation stage but that translation initiation did occur.

A recent study suggested that siRNAs derived from transgenes can mediate translation repression of the transgene mRNAs in planta (Brodersen et al. 2008). We investigated whether GFP siRNAs are associated with monosome or polysome fractions. The levels of GFP siRNAs were equivalent in the starting material extracted from plants that expressed only

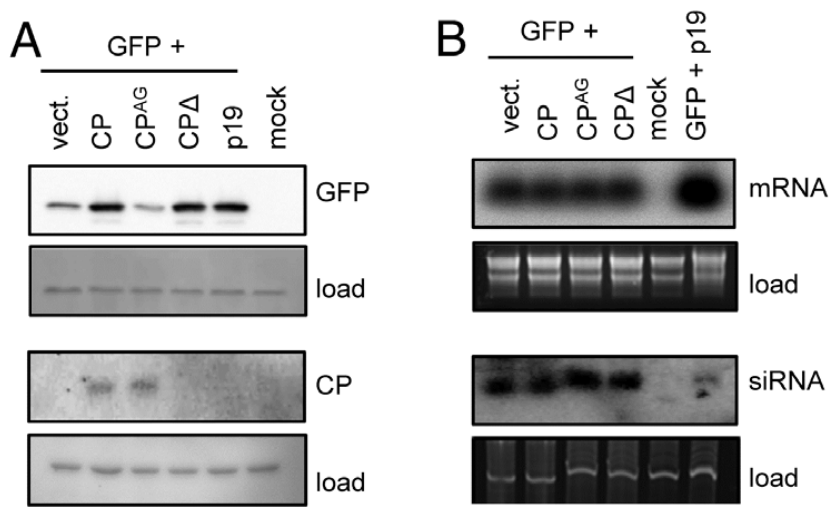

Fig. 2. A WG motif in the coat protein (CP) is critical for the CP-mediated enhancement of green fluorescent protein (GFP) expression in Nicotiana benthamiana. A, Steady-state levels of GFP and CP in plants transiently expressing GFP and wild-type or mutant derivatives of the ToRSV CP. Plants transiently expressing GFP alone (vect. $=$ the second Agrobacterium tumefaciens culture was transformed with empty vector) or GFP + tombusvirus p19 protein were used as controls for silencing suppression. Note that the $\mathrm{CP}$ antibodies were raised against a peptide corresponding to the C-terminal region of the $\mathrm{CP}$ and cannot recognize the CP $\Delta$ mutant. Mock = plants were infiltrated with A. tumefaciens cultures transformed with empty vectors and did not express GFP. Load $=$ Ponceau S staining of RbcS. B, Northern blotting of GFP mRNA and siRNAs extracted from the batch of plants used in A. Load = ethidium bromide staining of rRNAs.
GFP, GFP + CP, or GFP + CP ${ }^{\mathrm{AG}}$ (Fig. 4B). This was consistent with the observation that coexpression of GFP with CP did not affect the steady-state levels of GFP siRNAs (Fig. 2B). A large proportion of GFP siRNAs were associated with monosome fractions in GFP or GFP $+\mathrm{CP}^{\mathrm{AG}}$ samples but not in the GFP + CP samples (Fig. 4B). This result suggests that GFP siRNAs are involved in a translation repression mechanism, which is relieved by the WT $\mathrm{CP}$ but not by the $\mathrm{CP}^{\mathrm{AG}}$ mutant. We next tested whether the association of other types of sRNAs with monosomes was also altered by the ToRSV CP. miRNAs have been shown to direct translation repression in plants and are found in association with polysome or monosome fractions (Brodersen et al. 2008; Lanet et al. 2009). miR168 targets Agol mRNAs through transcript cleavage and translational repres-

A
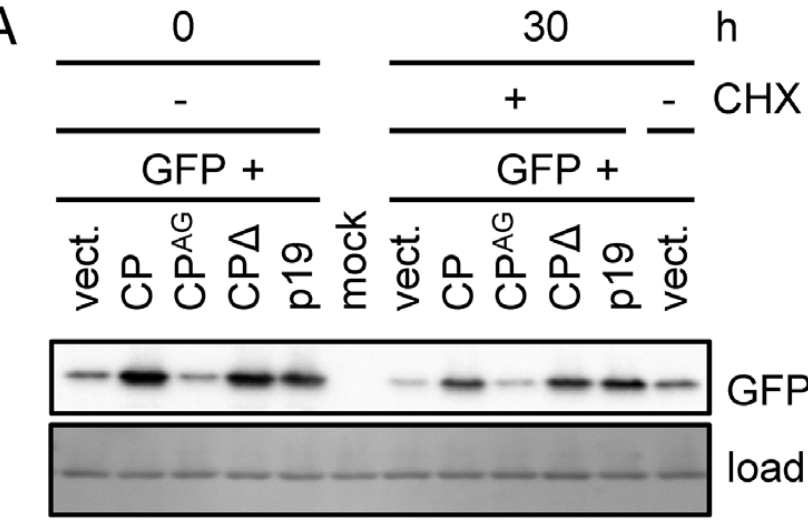

B
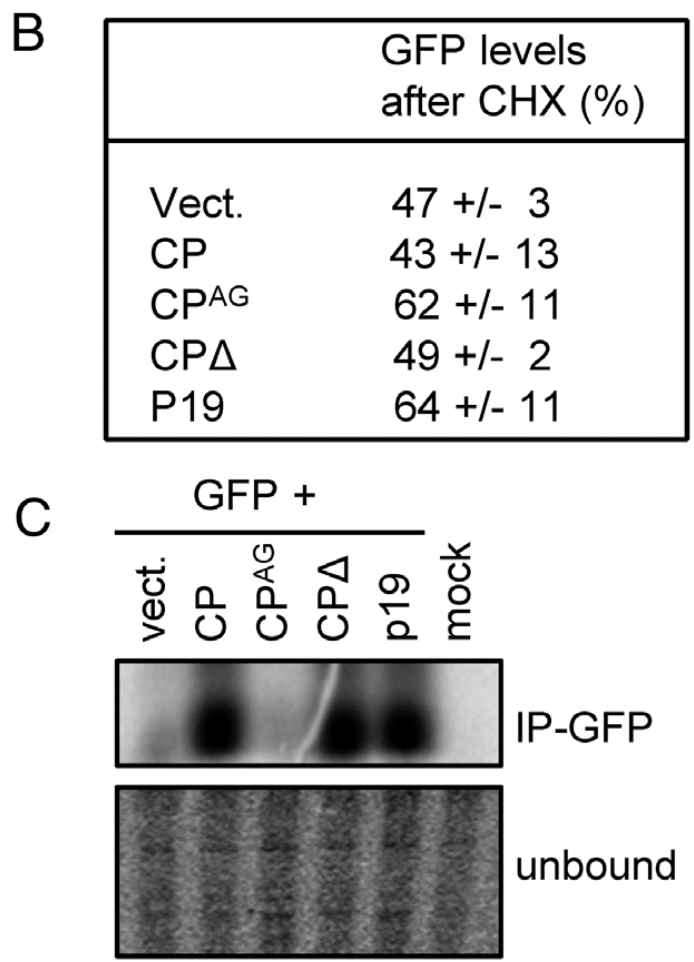

Fig. 3. Coat protein $(\mathrm{CP})$ does not affect the stability of green fluorescent protein (GFP) but enhances the rate of GFP translation. A, Analysis of the stability of GFP in the presence or absence of CP. Steady-state levels of GFP were analyzed before and after the cycloheximide ( $\mathrm{CHX}$ ) treatment (0 and $30 \mathrm{~h}$ ). Load = Coomassie blue staining of RbcS. B, Quantification of the relative steady-state levels of GFP following treatment with $\mathrm{CHX}$. Values are expressed as an average of three experiments with the standard deviation. C, In vivo labeling of newly synthesized GFP. The immunoprecipitated GFP protein (Ip-GFP) as well as the unbound fraction (an indicator of labeling of plant proteins) are shown. 
sion (Varallyay et al. 2010; Vaucheret 2009). miR159 is an abundant miRNA that regulates the expression of GAMYB-like genes (Alonso-Peral et al. 2010). Both miR168 and miR159 were associated with monosome fractions (Fig. 4B). miR159 was also associated with polysome fractions (Fig. 4B). However, the association of these miRNAs with monosomes or polysomes was not affected by coexpression of the ToRSV CP (Fig. 4B).

\section{Interaction between ToRSV CP and AGO1}

in a manner dependent on the WG motif.

The requirement for an intact WG motif for the ToRSV CPsilencing suppression activity suggests an interaction between an AGO protein and the CP. AGO1 was shown to be involved in sRNA-directed translation repression of mRNAs in a plant

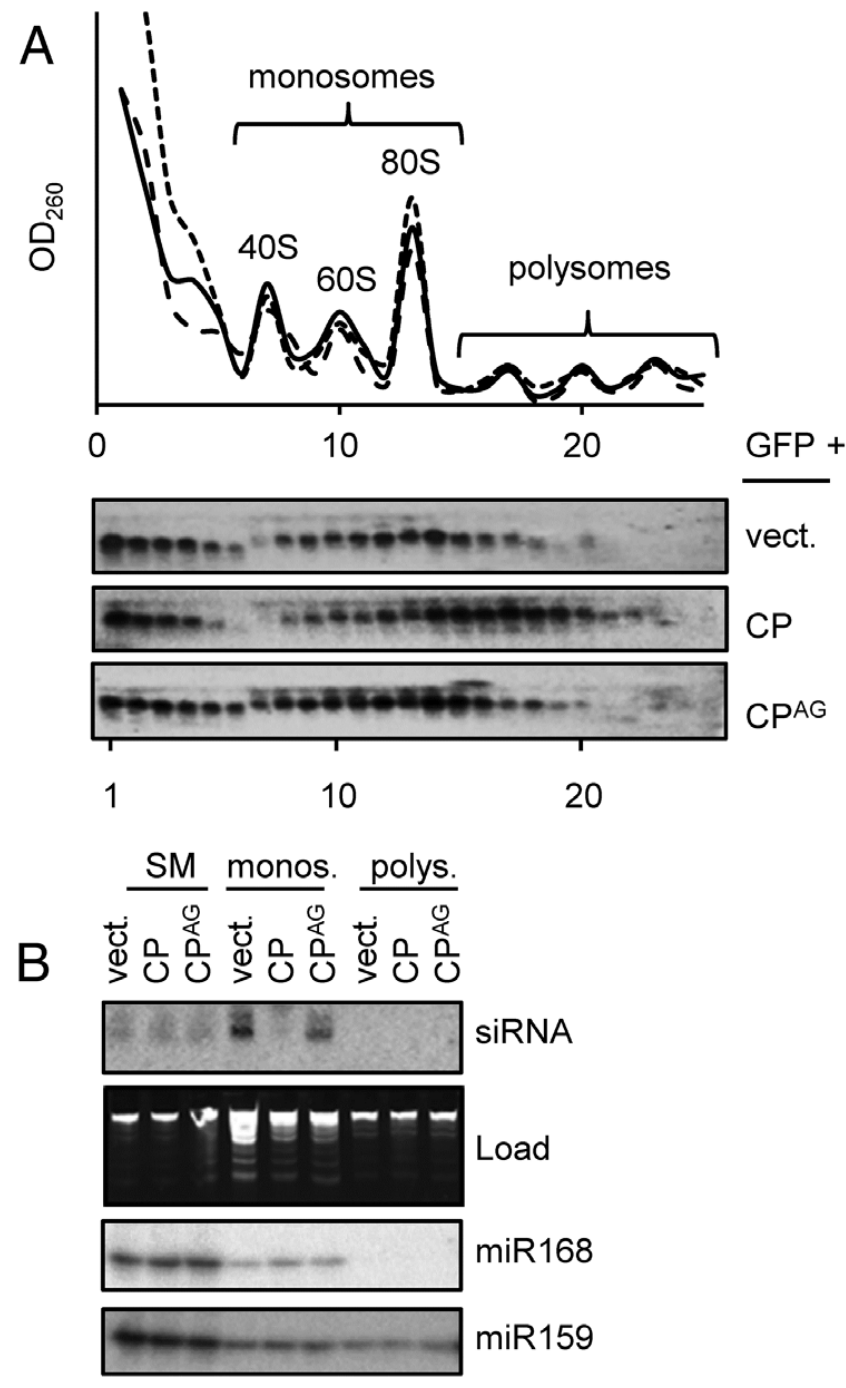

Fig. 4. Coat protein (CP) enhances the association of green fluorescent protein (GFP) mRNAs with polysomes and reduces the association of GFP siRNAs with monosomes. A, Polysome profiling of GFP mRNAs. Absorbance of individual sucrose gradient fraction is shown from lighter (14\% sucrose, fraction 1) to heavier (47\% sucrose, fraction 25). Solid line = $\mathrm{GFP}+\mathrm{CP}$, dotted line $=\mathrm{GFP}+\mathrm{CP}^{\mathrm{AG}}$, hashed line $=\mathrm{GFP}+$ empty vector Total RNAs were extracted from each fraction and probed for the presence of GFP mRNAs (lower panels). B, Association of GFP siRNAs with monosome fractions. Total RNA extracted from fractions corresponding to monosomes (monos, fractions 6 to 15) or from fractions corresponding to polysome (polys. fractions 16 to 25 ) were pooled separately. Aliquots of the pooled RNA were probed for GFP siRNA, miR168, and miR159. SM $=$ total RNA extracted from starting material prior to the sucrose gradient fractionation. Load $=$ ethidium bromide staining of rRNAs. in vitro system and in planta (Brodersen et al. 2008; Iwakawa and Tomari 2013). Translation repression of ToRSV RNA2 in infected plants was also shown to be dependent directly or indirectly on AGO1 (Ghoshal and Sanfacon 2014). For these reasons, we tested possible interactions between the ToRSV CP and AGO1. We conducted co-immunoprecipitation experiments from extracts derived from plants that expressed GFP, GFP + $\mathrm{CP}$, or $\mathrm{GFP}+\mathrm{CP}^{\mathrm{AG}}$. AGO1 was detected in the starting material from all extracts, although the steady-state levels of AGO1 were reduced in the plants that expressed GFP + CP (Fig. 5, lower panel). Both the $\mathrm{CP}$ and $\mathrm{CP}^{\mathrm{AG}}$ mutants were efficiently immunoprecipitated with CP-specific antibodies (Fig. 5). AGO1 was co-immunoprecipitated with the WT CP but not with the $\mathrm{CP}^{\mathrm{AG}}$ mutant (Fig. 5), suggesting that $\mathrm{CP}$ interacts with $\mathrm{AGO} 1$ and that this interaction depends on the presence of the WG motif.

\section{CP-mediated destabilization of AGO1.}

The results presented above indicate that steady-state levels of AGO1 are reduced in the presence of the ToRSV CP. We reexamined the accumulation of AGO1 protein and Agol mRNAs in plants expressing $\mathrm{CP}$ or the two mutated versions of CP. As shown above, accumulation of AGO1 was reduced in the presence of $\mathrm{CP}$ or $\mathrm{CP} \Delta$ but not in the presence of $\mathrm{CP}^{\mathrm{AG}}$ (Fig. 6). In contrast, the levels of Agol mRNAs were similar in all samples. Several viral-silencing suppressors have been reported to cause an induction of miR168 expression, resulting in a downregulation of Agol translation (Varallyay and Havelda 2013; Varallyay et al. 2010). Accumulation of miR168 was similar in cells expressing $\mathrm{CP}, \mathrm{CP}^{\mathrm{AG}}$, or $\mathrm{CP} \Delta$ (Fig. 6). Therefore, this could not account for the reduction in AGO1 protein levels in plants expressing the WT CP and $\mathrm{CP} \Delta$, but not in plants expressing $C P^{\mathrm{AG}}$.

The P0 VSR has been suggested to direct the degradation of AGO1 through the autophagy pathway (Derrien et al. 2012) while the P25 VSR was proposed to destabilize AGO1 using

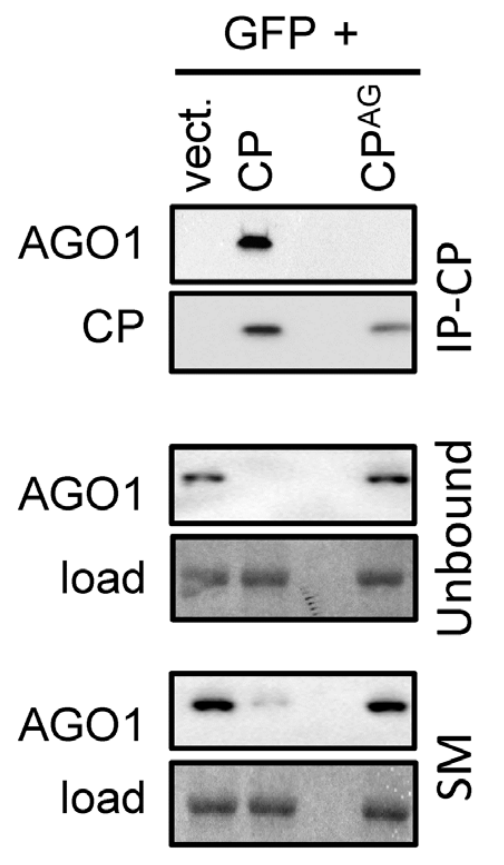

Fig. 5. Co-immunoprecipitation of $\mathrm{AGO} 1$ with the coat protein $(\mathrm{CP})$. $\mathrm{CP}$ was immunoprecipitated using an antibody specific for the C-terminal region. The starting material (SM), immunoprecipitated fractions (IP-CP), and unbound fractions were analyzed for the presence of $\mathrm{CP}$ and Agol. Please note that the IP-CP fractions were 25 times more concentrated than the $\mathrm{SM}$ and unbound fractions. Load = Ponceau S staining of RbcS. 
the proteasome pathway (Chiu et al. 2010). We used known inhibitors of the autophagy pathway (E64D, which also inhibits most vacuolar proteases) and of the proteasome pathway (MG132), and monitored the level of AGO1. Accumulation of polyubiquitinated proteins in MG132-treated leaves (Fig. 7B) confirmed that inhibition of the proteasome pathway was occurring. However, destabilization of AGO1 in cells expressing the CP was not prevented by MG132 (Fig. 7A). In contrast, AGO1 was stabilized in the presence of E64D in the CP and $\mathrm{CP} \Delta$ samples (Fig. 7A). These results suggest that the ToRSV $\mathrm{CP}$ accelerates the degradation of $\mathrm{AGO} 1$ and that a protease inhibited by E64d is responsible directly or indirectly for this degradation.

\section{DISCUSSION}

In this study, we have identified the ToRSV CP as a VSR and explored the silencing suppression mechanism. VSR interfere with many different steps in the RNA-silencing pathway but all plant VSR characterized thus far eventually lead to inhibition of mRNA cleavage (Burgyan and Havelda 2011). Using a welldescribed transient expression assay and the GFP reporter gene, we have shown that the ToRSV CP enhances the translation of GFP mRNAs but does not prevent the degradation of this RNA. Our results suggest that the ToRSV CP interacts with AGO1 and accelerates its degradation. A WG motif in the ToRSV CP is required for silencing suppression, AGO1 binding, and $\mathrm{CP}$ mediated AGO1 degradation. Our results also show that silencing of transiently expressed GFP in $N$. benthamiana is due, in part, to AGO1-mediated translation repression.

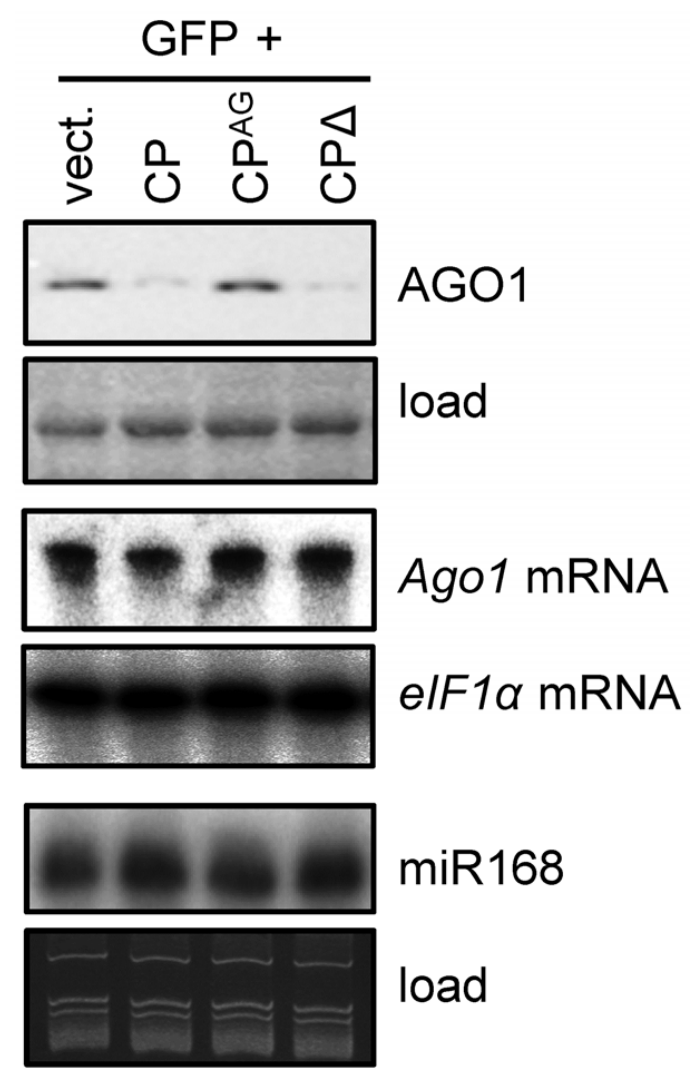

Fig. 6. Steady-state levels of AGO1, Agol mRNA, and miR168 in leaves transiently expressing green fluorescent protein (GFP) and various forms of the coat protein (CP). Steady-state levels of AGO1 protein (top panels), Agol mRNA (middle panels), and miR168 (bottom panels). eIFl $\alpha$ mRNA is shown as load control for Agol mRNA. Ethidium bromide staining of rRNAs is shown as load control for the miR 168 blot.
The WG motif in the ToRSV CP is located in the A domain, which is the functional equivalent to the CPMV small CP (Fig. 1), a previously identified suppressor of silencing (Canizares et al. 2004). However, a WG motif is not present at this or other positions in the CPMV small CP. Deletion of the C-terminal extension of the CPMV small CP eliminated its silencing suppression activity (Canizares et al. 2004). In contrast, a truncated ToRSV CP with a similar mutation retained silencing suppression activity. Also, whereas the CPMV small CP inhibited GFP mRNA degradation (Canizares et al. 2004), the ToRSV $\mathrm{CP}$ did not. Thus, although the two proteins are phylogenetically and structurally related, they have distinct mechanisms to suppress silencing.

GW/WG repeats are interchangeable modular domains present in a large variety of cellular proteins that regulate various aspects of RNA silencing. The number of GW/WG repeats varies from 2 to 40. It has been suggested that two Ws are required for optimal binding to human AGO2 (Pfaff et al. 2013), although peptides or protein fragments that contain a single WG/GW motif can bind AGOs (Azevedo et al. 2010; Pfaff et al. 2013; Takimoto et al. 2009). Similarly, both the p38 and P1 VSR require a minimum of two WG/GW motifs to bind to the plant AGO1 and suppress silencing (Azevedo et al. 2010; Giner et al. 2010). A single WG motif is present in the ToRSV $\mathrm{CP}$ and mutation of this motif abrogated AGO1 binding and silencing suppression. Recent evidence suggests that a flanking $G$ is not a strict requirement for AGO binding and that other amino acids with small side chains flanking $\mathrm{W}$ residues are acceptable substitutes (Pfaff et al. 2013). Further work will be necessary to determine whether other $\mathrm{W}$ residues present in the ToRSV CP sequence also participate in AGO1 binding. In addition, it is also possible that the ToRSV CP interacts with AGO1 as a dimer, bringing the two WG motifs present in each $\mathrm{CP}$ subunit in close proximity. The $\mathrm{W}$ of the ToRSV CP WG motif is highly conserved among nepoviruses, although it is not always flanked by a $\mathrm{G}$ (Fig. 1B). In addition, other GW and WG motifs were identified in nepovirus CP (Fig. 1B). Thus, binding to AGO1 may be a conserved feature among nepovirus CP.

The ToRSV WG motif is not predicted to be exposed in assembled virus particles (Fig. 1C and D). therefore, during viral infections, binding to AGO1 and suppression of translation repression may be transient but could occur immediately after decapsidation. This is consistent with the observation that ToRSV infection delays but does not prevent systemic silencing of a GFP transgene (Jovel et al. 2007). Temperature-dependent symptom recovery during ToRSV infection was recently shown to be associated with AGO1-dependent translation repression of viral RNA2 (Ghoshal and Sanfacon 2014). It was suggested that the translation repression may allow the viral RNA to persist in infected plants but evade recognition by other plant defense responses such as necrotic responses, which are likely triggered by the accumulation of viral proteins (Ghoshal and Sanfacon 2014). Thus, the virus may benefit from the induction of a translation repression mechanism, and may only counteract this mechanism under certain circumstances (e.g., lower temperatures). Further work will be necessary to evaluate the role of the ToRSV CP silencing-suppression activity during viral infection. Unfortunately, ToRSV infectious clones are currently unavailable, precluding us from mutating the CP WG motif in the context of the viral genome.

Destabilization of AGO1 in the presence of the ToRSV CP required the presence of the $\mathrm{WG}$ motif in the ToRSV CP, indicating that it depends on an interaction between $\mathrm{CP}$ and AGO1. In contrast, interaction of the WG/GW motifs containing p38 and P1 VSR with AGO1 did not lead to its degradation (Azevedo et al. 2010; Giner et al. 2010). Thus, although the 
CP WG motif is required for AGO1 degradation, other features of the CP-AGO1 interaction likely contribute to this process.

Although both $\mathrm{AGO} 1$ and $\mathrm{AGO} 2$ have been implicated in antiviral silencing (Carbonell et al. 2012; Harvey et al. 2011; Jaubert et al. 2011; Morel et al. 2002; Qu et al. 2008; Scholthof et al. 2011; Wang et al. 2011), downregulation of AGO2 does not prevent silencing of transiently expressed GFP in $N$. benthamiana (Scholthof et al. 2011). The results presented here show that destabilization of AGO1 by the ToRSV CP suppresses the GFP silencing, indicating that AGO1 is involved in this process. AGO1 plays diverse roles in plant RNA silencing pathways, including mRNA cleavage and mRNA translation repression directed by siRNAs or miRNAs (Brodersen et al. 2008; Iwakawa and Tomari 2013; Mallory and Vaucheret 2010; Vaucheret 2008). Although AGO1 is destabilized in the presence of the ToRSV CP (Fig. 7), GFP mRNA degradation is not prevented (Fig. 2). How can we reconcile these apparently conflicting observations? Closer examination of the results revealed that not all AGO1 molecules are degraded in the presence of the $\mathrm{CP}$ (Fig. 7). Thus, only a subpopulation of AGO1, probably one that is not involved in GFP mRNA slicing and possibly one that is involved in translation repression, may be destabilized in the presence of CP. Although A. thaliana encodes a single Agol gene, selective suppression of siRNA or miRNA loading by various VSR led to the suggestion that at least two distinct pools of AGO1 coexist in plants, which are separated by binding to different factors or by subcellular localization (Schott et al. 2012). In N. benthamiana, two Agol-like genes (NbAgol-1 and NbAgol-2) have been identified that share $88 \%$ sequence identity at the amino acid level (Jones et al. 2006). The two AGO1s may have different activities, separate in different subcellular localization, or bind
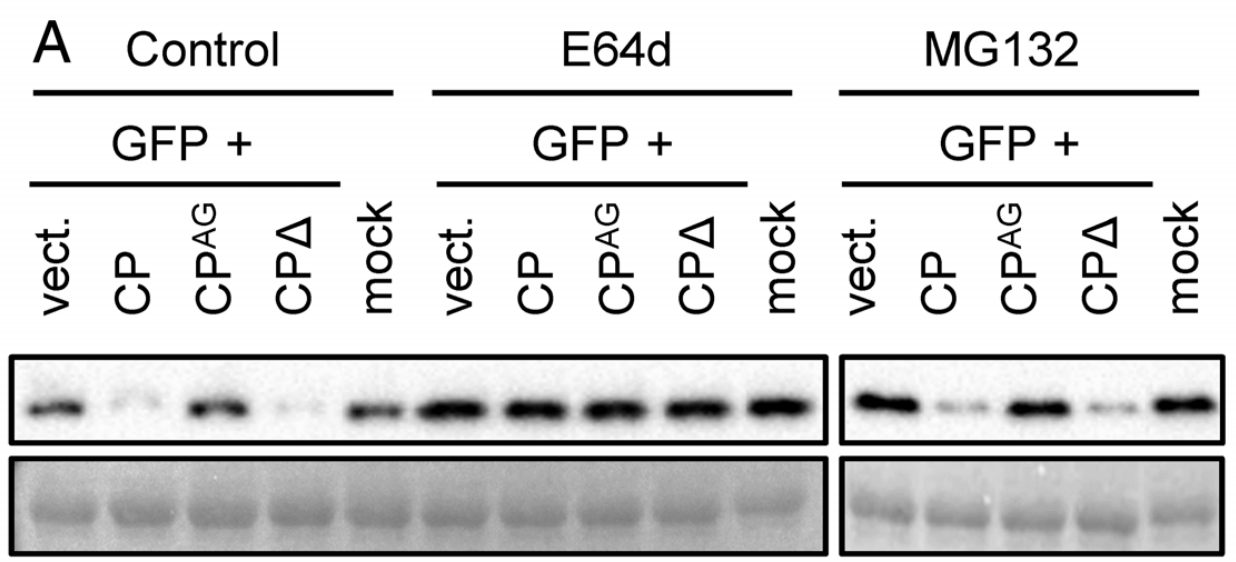

AGO1

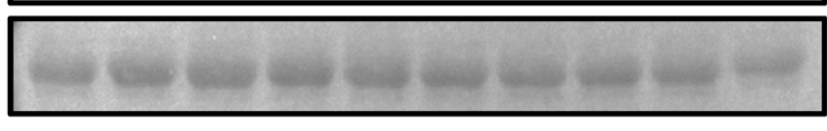

load
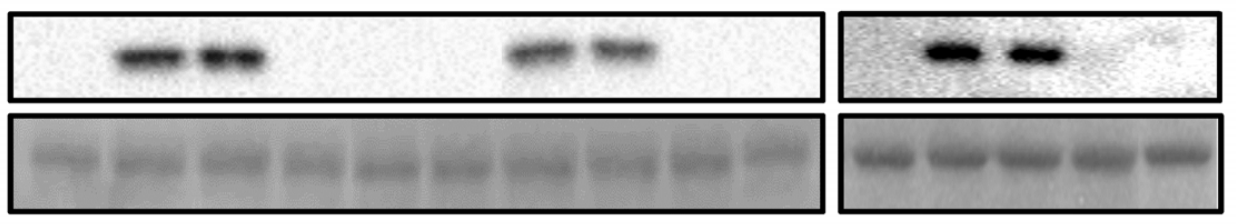

$\mathrm{CP}$

load

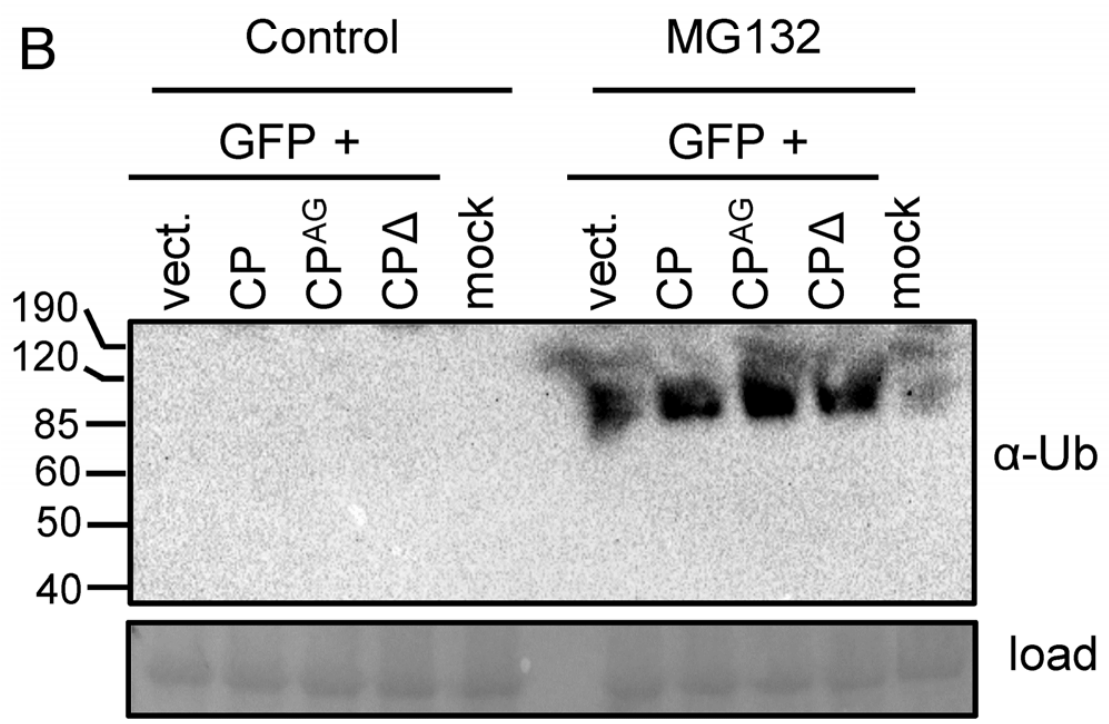

Fig. 7. Coat protein (CP)-mediated degradation of AGO1 is blocked by an inhibitor of the autophagy pathway. A, Inhibition of protein degradation pathways Leaves expressing green fluorescent protein (GFP) alone (vect.) or in combination with various forms of the CP were treated with an inhibitor of the autophagy pathway (E64d) or of the proteasome pathway (MG132). Control $=$ buffer solution without inhibitors. Mock $=$ leaves that were only agroinfiltrated with Agrobacterium tumefaciens containing the empty vector. AGO1 and CP steady-state levels were analyzed. B, Accumulation of polyubiquitinated proteins in the presence of MG132. A replicate Western blot from A was probed with anti-ubiquitin antibody. 
to the ToRSV CP with different efficiencies. Unfortunately, the antibodies used in our study recognize both proteins and would not allow separation of the activities of each AGO1. Finally, the activity and subcellular localization of AGOs can be regulated by post-translational modifications, such as phosphorylation. Indeed, phosphorylation of human AGO2 suppresses its sRNA-binding and mRNA-slicing activities but enhances its localization to P-bodies and its miRNA-directed mRNA translation repression activity (Horman et al. 2013; Rudel et al. 2011; Zeng et al. 2008). It is possible that similar post-translational modifications participate in the separation of distinct cellular pools of the plant AGO1, each of which is recognized with different efficiencies by the ToRSV CP.

Although translation repression and RNA slicing can target the same mRNA, the two mechanisms can be genetically separated. Mutations in Ampl, an endoplasmic reticulum integral membrane protein; KTN1, a microtubule-severing enzyme; Vcsl, a component of the mRNA decapping complex; and $S U O$, a cellular GW-repeat protein, resulted in increased protein levels of miRNA-targeted or siRNA-targeted genes but not of the corresponding mRNA, suggesting that they affect translation repression but not RNA slicing (Brodersen et al. 2008; Li et al. 2013; Yang et al. 2012). Similarly, we now show that the ToRSV CP inhibits translation repression of the GFP mRNAs without affecting their susceptibility to slicing. In contrast, other characterized plant VSR affect RNA slicing (Burgyan and Havelda 2011), sometimes exclusively of translation repression (e.g., the cucumovirus $2 \mathrm{~b}$ protein) (Lanet et al. 2009).

In animal cells, miRNA-directed translation repression was proposed to function either at a post-initiation step (Kim et al. 2004; Petersen et al. 2006) or at the initiation stage (Chendrimada et al. 2007; Thermann and Hentze 2007). In plant cells, association of miRNAs with monosome and polysome fractions was correlated with target mRNA repression, suggesting that they inhibit translation post-initiation (Lanet et al. 2009). In vitro experiments suggested that, depending on the position of the miRNA binding site on the mRNA target, AGO1-directed translation repression could act either at an early translation initiation step by preventing the formation of the $48 \mathrm{~S}$ complex or during elongation by sterically blocking ribosome movement (Iwakawa and Tomari 2013). Our observation that the ToRSV CP prevents the association of GFP siRNAs with monosome fractions suggests a post-initiation translation repression mechanism under our experimental conditions. Taken together, our results are consistent with the suggestion that the ToRSV CP functions as an AGO-hook protein and competes for AGO binding with a plant cellular GW/WG protein involved in translation repression.

\section{MATERIALS AND METHODS}

\section{Plasmid construction.}

Binary vectors allowing the expression of the TBSV p19 VSR and the GFP reporter gene have been described (Zhang et al. 2005). A binary vector containing the CP coding region of ToRSV isolate PYB (pBIN-CP) was designed by amplifying this region from available cDNA clones using primers $\mathrm{CP}-\mathrm{F}$ (5' CTAGTATCTAGAGGCGGGTCAT GGCAAGAA 3', including an underlined $X b a \mathrm{I}$ restriction site) and CP-R (5' CTAGTATCTAGATTAACCACGCCCGAAAGGAT $3^{\prime}$, also including an $X b a \mathrm{I}$ site), and ligating the $\mathrm{XbaI}$-digested insert into the corresponding site of the pBB125 vector (Sun et al. 2001). The expression cassette containing the duplicated $35 \mathrm{~S}$ promoter, the $\mathrm{CP}$ coding region, and the nos polyadenylation signal was digested with XhoI and SacI and inserted into the SacI-SalI sites of binary vector $\mathrm{pBIN}^{+}$to create $\mathrm{pBIN-CP}$. For mutations and deletions, the QuickChange II-E Site-Directed Mutagenesis protocol was used (Stratagene, La Jolla, CA, U.S.A.). The $\mathrm{CP}^{\mathrm{AG}}$ mutant was constructed using overlapping primers CP-AG-F (5' CAGGCGGGTTTG AATACTACTGCT GGGAAT 3', mutation underlined) and CP-AG-R (5' ATTCA AACCCGCCTGGAAAACGAAAATGGC $3^{\prime}$ ) to mutate $\mathrm{W}^{412}$ to A. For $\mathrm{CP} \Delta$, overlapping primers $\mathrm{CP} \Delta-\mathrm{F}\left(5^{\prime}\right.$ TAATCTAGA CGGATCCCCGATCGTTCAAACATTTGG 3') and CP $\Delta-\mathrm{R}$ (5' CGTCTAGATTAGAAATGTTTAACACTAGGTCCATAG AAAGAAAATCCC $3^{\prime}$ ) were used to delete the coding region for the C-terminal 51 amino acids of $\mathrm{CP}$.

\section{Agroinfiltrations.}

All described experiments were conducted at least three times on independent batches of plants with similar results. Agroinfiltrations were conducted as described (Zhang et al. 2005). Following agroinfiltration, plants were kept in a growth chamber at $21^{\circ} \mathrm{C}$ with a day-night cycle of 16 and $8 \mathrm{~h}$, respectively. Agroinfiltrated leaves were collected at 4 days postagroinfiltration (dpa). To minimize leaf-to-leaf variation, pools of three to four leaves were analyzed to determine protein or RNA steady-state levels (see below).

\section{Protein analysis.}

To examine the protein steady-state levels, leaves were extracted and Western blot analysis were conducted as described (Han and Sanfacon 2003). Polyclonal rabbit antibodies corresponding to the $\mathrm{C}$-terminal region of ToRSV CP were raised against the peptide TLETNNPVGRPPENVD. Antibodies against $N$. benthamiana AGO1 were kindly provided by $\mathrm{J}$. Burgyan (Varallyay et al. 2010). Commercial ubiquitin polyclonal antibody (Sigma, St. Louis) and GFP monoclonal antibody (Clontech, Mountain View, CA, U.S.A) were also used. Antibody-protein interactions were visualized using a chemidoc imaging system (Bio-Rad, Mississauga, Ontario).

\section{RNA isolation and detection.}

To analyze GFP mRNAs steady-state levels, total RNA was extracted using trizol, separated on denaturing gels, and probed by Northern blotting, as described (Jovel et al. 2007). Membranes were hybridized with radiolabeled cDNA probes and bands were visualized using a phosphorimager. For detection of mRNAs with low abundance (Ago1), mRNAs were purified from $75 \mu \mathrm{g}$ of total RNA using oligo dT-bound Dynabeads (New England Biolabs, Beverly, MA, U.S.A.). Purified mRNAs $(1 \mu \mathrm{g})$ were separated on denaturing gels and transferred to nylon membranes. For probes, cDNA fragments were amplified using previously described primers for eIFl $\alpha$ (Bhattacharjee et al. 2009), Agol (Ghoshal and Sanfacon 2014), or the following forward (F) and reverse (R) primers for GFP: GFP-F (5' ATGAGTAAAGGAGAAGAACT 3') and GFP-R (5'CAAACTCAAGAAGGACCATG3'). For sRNA detection, $15 \mu \mathrm{g}$ of total RNA was separated on a gel $(8 \mathrm{M}$ urea and $15 \%$ acrylamide and probed at 38 instead of $65^{\circ} \mathrm{C}$ by Northern blot analysis. The GFP probe was used to detect GFP siRNA, and locked nucleic acid probes were used to detect miR159 (5' TTTGGATTGAAGGGAGCTCTA $\left.3^{\prime}\right)$ and miR168 (5' TCGCTTGGTGCAGGTC GGG AA 3').

\section{In vivo labeling experiment and immunoprecipitation.}

In vivo labeling of detached leaves was performed at $4 \mathrm{dpa}$ by incubating the petioles in water $(800 \mu \mathrm{l})$ containing $20 \mu \mathrm{Ci}$ of $\left[{ }^{35} \mathrm{~S}\right]$-methionine and $2 \mu \mathrm{M}$ cold methionine for $4 \mathrm{~h}$ at room temperature. Pools of three to four labeled leaves were extracted and immunoprecipitations were conducted as described (Schott et al. 2012) using a GFP monoclonal antibody (Clontech). Proteins were separated by sodium dodecyl sulfate (SDS) 
polyacrylamide gel electrophoresis and bands were visualized using a phosphorimager.

\section{Polysome profiles.}

Leaf tissue $(0.2 \mathrm{~g}$, pooled from three to four leaves collected at $4 \mathrm{dpa}$ ) was pulverized in liquid nitrogen before resuspension in $1 \mathrm{ml}$ of lysis buffer $(140 \mathrm{mM} \mathrm{NaCl}, 10 \mathrm{mM}$ HEPES [pH 7.5], $10 \mathrm{mM}$ Complete EDTA-Free protease inhibitor [Roche, Mannheim, Germany], $7 \mathrm{mM} \mathrm{MgCl}_{2}, 3 \mathrm{mM} \mathrm{CaCl}, 0.1 \mathrm{mM}$ dithiothreitol [DTT], $0.5 \%$ NP-40, heparin at $650 \mu \mathrm{g} / \mathrm{ml}$, cycloheximide at $150 \mu \mathrm{g} / \mathrm{ml}$, and RNA guard (GE Healthcare, Mississauga, Ontario] at $250 \mathrm{U} / \mathrm{ml}$ ). Cells were lysed by pipetting up and down several times and centrifuged at $12,000 \times g$ at $4{ }^{\circ} \mathrm{C}$ for 5 min. The lysate (25 A260 units) was loaded on a sucrose gradient of 14 to $47 \%$ prepared in $140 \mathrm{mM} \mathrm{NaCl}, 7$ $\mathrm{mM} \mathrm{MgCl} 2,3 \mathrm{mM} \mathrm{CaCl} 2,0.1 \mathrm{mM}$ DTT, cycloheximide at 100 $\mu \mathrm{g} / \mathrm{ml}$, and heparin at $0.5 \mathrm{mg} / \mathrm{ml}$. Gradients were centrifuged in a SW41Ti rotor (Beckman) at 38,000 rpm at $4^{\circ} \mathrm{C}$ for $2 \mathrm{~h}$. Fractions were collected and A260 readings were recorded. Fractions were incubated with $10 \mathrm{mM}$ EDTA, 1\% SDS, and proteinase $\mathrm{K}$ at $10 \mu \mathrm{g} / \mathrm{ml}$ for $30 \mathrm{~min}$ at $37^{\circ} \mathrm{C}$, and RNA was recovered by extraction with trizol.

\section{Treatment with inhibitors.}

Leaves were detached at $3 \mathrm{dpa}$ and petioles were submerged in water ( $1 \mathrm{ml})$ containing either $20 \mu \mathrm{M}$ E64d (Sigma), $50 \mu \mathrm{M}$ MG132 (Sigma)m or water only for $24 \mathrm{~h}$ at room temperature before samples (pools of three to four leaves) were processed for Western blot analysis. Experiments with cycloheximide (30 $\mu \mathrm{g} / \mathrm{ml}$ ) were conducted in a similar manner but incubated for $30 \mathrm{~h}$ at room temperature.

\section{Alignments and accession numbers.}

Sequence alignments were conducted using the ClustalW program. Accession numbers used for the alignments presented in Figure 1 are as follows: ToRSV-PYB (AAD50654), ToRSVRasp1 (AAD50653), ToRSV-Rasp2 (NP_733973), ToRSVGYV (AAD50653), BRV (AF020051), Blueberry leaf mottle virus (AAA64608), Artichoke yellow ringspot virus (ABM65096), TRSV (AY363727), GFLV (X16907), ArMV (YP054438), Grapevine chrome mosaic virus (X15163), Tomato black ring virus, isolate MJ (TBRV-MJ; AY157994), TBRV-ED (X80831), Artichoke Italian latent virus (X87254), Cycas necrotic stunt virus (AB073148), Grapevine Anatolian ringspot virus (AAQ56596), and CPMV (X00729). The Cn3D program was used to represent the ribbon models of the GFLV CP.

\section{ACKNOWLEDGMENTS}

We thank M. Walker for performing the initial steps of the CP cloning, J. Burgyan (Agricultural Biotechnology Center, Hungary) for the NbAGO1 antibodies, C. Ritzenthaler (IBMP, Strasbourg) for helpful discussions, and J. Chisholm for critical reading of the manuscript

\section{LITERATURE CITED}

Alonso-Peral, M. M., Li, J., Li, Y., Allen, R. S., Schnippenkoetter, W., Ohms, S., White, R. G., and Millar, A. A. 2010. The microRNA159-regulated GAMYB-like genes inhibit growth and promote programmed cell death in Arabidopsis. Plant Physiol. 154:757-771.

Alvarado, V., and Scholthof, H. B. 2009. Plant responses against invasive nucleic acids: RNA silencing and its suppression by plant viral pathogens. Semin. Cell Dev. Biol. 20:1032-1040.

Azevedo, J., Garcia, D., Pontier, D., Ohnesorge, S., Yu, A., Garcia, S. Braun, L., Bergdoll, M., Hakimi, M. A., Lagrange, T., and Voinnet, O. 2010. Argonaute quenching and global changes in Dicer homeostasis caused by a pathogen-encoded GW repeat protein. Genes Dev. 24:904915
Baumberger, N., and Baulcombe, D.C. 2005. Arabidopsis ARGONAUTE1 is an RNA Slicer that selectively recruits microRNAs and short interfering RNAs. Proc. Natl. Acad. Sci. U.S.A. 102:11928-11933.

Bhattacharjee, S., Zamora, A., Azhar, M. T., Sacco, M. A., Lambert, L. H., and Moffett, P. 2009. Virus resistance induced by NB-LRR proteins involves Argonaute4-dependent translational control. Plant J. 58:940-951.

Bortolamiol, D., Pazhouhandeh, M., Marrocco, K., Genschik, P., and Ziegler-Graff, V. 2007. The Polerovirus F Box Protein P0 Targets ARGONAUTE1 to Suppress RNA Silencing. Curr. Biol. 17:1615-1621.

Braun, J. E., Huntzinger, E., Fauser, M., and Izaurralde, E. 2011. GW182 proteins directly recruit cytoplasmic deadenylase complexes to miRNA targets. Mol. Cell 44:120-133.

Brodersen, P., and Voinnet, O. 2006. The diversity of RNA silencing pathways in plants. Trends Genet. 22:268-280.

Brodersen, P., Sakvarelidze-Achard, L., Bruun-Rasmussen, M., Dunoyer, P., Yamamoto, Y. Y., Sieburth, L., and Voinnet, O. 2008. Widespread translational inhibition by plant miRNAs and siRNAs. Science 320:1185-1190.

Burgyan, J., and Havelda, Z. 2011. Viral suppressors of RNA silencing. Trends Plant Sci. 16:265-272.

Canizares, M. C., Taylor, K. M., and Lomonossoff, G. P. 2004. Surface-exposed C-terminal amino acids of the small coat protein of Cowpea mosaic virus are required for suppression of silencing. J. Gen. Virol. 85:3431-3435.

Carbonell, A., Fahlgren, N., Garcia-Ruiz, H., Gilbert, K. B., Montgomery, T. A., Nguyen, T., Cuperus, J. T., and Carrington, J. C. 2012. Functional analysis of three Arabidopsis ARGONAUTES using slicer-defective mutants. Plant Cell 24:3613-3629.

Chandrasekar, V., and Johnson, J. E. 1998. The structure of tobacco ringspot virus: A link in the evolution of icosahedral capsids in the picornavirus superfamily. Structure 6:157-171.

Chendrimada, T. P., Finn, K. J., Ji, X., Baillat, D., Gregory, R. I., Liebhaber, S. A., Pasquinelli, A. E., and Shiekhattar, R. 2007. MicroRNA silencing through RISC recruitment of eIF6. Nature 447:823-828.

Chiu, M.-H., Chen, I.-H., Baulcombe, D. C., and Tsai, C.-H. 2010. The silencing suppressor P25 of Potato virus $X$ interacts with Argonaute 1 and mediates its degradation through the proteasome pathway. Mol. Plant Pathol. 11:641-649.

Csorba, T., Pantaleo, V., and Burgyan, J. 2009. RNA silencing: An antiviral mechanism. Adv. Virus Res. 75:35-71.

Csorba, T., Lozsa, R., Hutvagner, G., and Burgyan, J. 2010. Polerovirus protein P0 prevents the assembly of small RNA-containing RISC complexes and leads to degradation of ARGONAUTE1. Plant J. 62:463472.

Czech, B., and Hannon, G. J. 2011. Small RNA sorting: Matchmaking for Argonautes. Nat. Rev. Genet. 12:19-31.

Derrien, B., Baumberger, N., Schepetilnikov, M., Viotti, C., De Cillia, J. Ziegler-Graff, V., Isono, E., Schumacher, K., and Genschik, P. 2012. Degradation of the antiviral component ARGONAUTE1 by the autophagy pathway. Proc. Natl. Acad. Sci. U.S.A. 109:15942-15946.

El-Shami, M., Pontier, D., Lahmy, S., Braun, L., Picart, C., Vega, D., Hakimi, M. A., Jacobsen, S. E., Cooke, R., and Lagrange, T. 2007. Reiterated WG/GW motifs form functionally and evolutionarily conserved ARGONAUTE-binding platforms in RNAi-related components. Genes Dev. 21:2539-2544.

Ender, C., and Meister, G. 2010. Argonaute proteins at a glance. J. Cell Sci. 123:1819-1823.

Ghildiyal, M., and Zamore, P. D. 2009. Small silencing RNAs: An expanding universe. Nat. Rev. Genet. 10:94-108.

Ghoshal, B., and Sanfacon, H. 2014. Temperature-dependent symptom recovery in Nicotiana benthamiana plants infected with Tomato ringspot virus is associated with reduced translation of viral RNA2 and requires ARGONAUTE 1. Virology 456-457:188-197.

Giner, A., Lakatos, L., Garcia-Chapa, M., Lopez-Moya, J. J., and Burgyan, J. 2010. Viral protein inhibits RISC activity by Argonaute binding through conserved WG/GW motifs. PLoS Pathog. 6:e1000996. Published online.

Han, S., and Sanfacon, H. 2003. Tomato ringspot virus proteins containing the nucleoside triphosphate binding domain are transmembrane proteins that associate with the endoplasmic reticulum and cofractionate with replication complexes. J. Virol. 77:523-534.

Harvey, J. J., Lewsey, M. G., Patel, K., Westwood, J., Heimstadt, S., Carr, J. P., and Baulcombe, D. C. 2011. An antiviral defense role of AGO2 in plants. PLoS One 6:e14639. Published online.

Horman, S. R., Janas, M. M., Litterst, C., Wang, B., MacRae, I. J., Sever, M. J., Morrissey, D. V., Graves, P., Luo, B., Umesalma, S., Qi, H. H., Miraglia, L. J., Novina, C. D., and Orth, A. P. 2013. Akt-mediated phosphorylation of Argonaute 2 downregulates cleavage and upregulates translational repression of MicroRNA targets. Mol. Cell 50:356-367.

Huntzinger, E., and Izaurralde, E. 2011. Gene silencing by microRNAs: 
Contributions of translational repression and mRNA decay. Nat. Rev. Genet. 12:99-110

Hutvagner, G., and Simard, M. J. 2008. Argonaute proteins: Key players in RNA silencing. Nat. Rev. Mol. Cell Biol. 9:22-32.

Iwakawa, H. O., and Tomari, Y. 2013. Molecular insights into microRNAmediated translational repression in plants. Mol. Cell 52:591-601.

Jaubert, M., Bhattacharjee, S., Mello, A. F., Perry, K. L., and Moffett, P. 2011. ARGONAUTE2 mediates RNA-silencing antiviral defenses against Potato virus $X$ in Arabidopsis. Plant Physiol. 156:1556-1564.

Ji, L., Liu, X., Yan, J., Wang, W., Yumul, R. E., Kim, Y. J., Dinh, T. T., Liu, J., Cui, X., Zheng, B., Agarwal, M., Liu, C., Cao, X., Tang, G., and Chen, X. 2011. ARGONAUTE10 and ARGONAUTE1 regulate the termination of floral stem cells through two microRNAs in Arabidopsis. PLoS Genet. 7:e1001358. Published online.

Jones, L., Keining, T., Eamens, A., and Vaistij, F. E. 2006. Virus-induced gene silencing of Argonaute genes in Nicotiana benthamiana demonstrates that extensive systemic silencing requires Argonaute1-like and Argonaute4-like genes. Plant Physiol. 141:598-606.

Jovel, J., Walker, M., and Sanfacon, H. 2007. Recovery of Nicotiana benthamiana plants from a necrotic response induced by a nepovirus is associated with RNA silencing but not with reduced virus titer. J. Virol. 81:12285-12297.

Karlowski, W. M., Zielezinski, A., Carrere, J., Pontier, D., Lagrange, T., and Cooke, R. 2010. Genome-wide computational identification of WG/GW Argonaute-binding proteins in Arabidopsis. Nucleic Acids Res. 38:4231-4245

Katiyar-Agarwal, S., and Jin, H. 2010. Role of small RNAs in hostmicrobe interactions. Annu. Rev. Phytopathol. 48:225-246.

Kim, J., Krichevsky, A., Grad, Y., Hayes, G. D., Kosik, K. S., Church, G. M., and Ruvkun, G. 2004. Identification of many microRNAs that copurify with polyribosomes in mammalian neurons. Proc. Natl. Acad. Sci. U.S.A. 101:360-365.

Krol, J., Loedige, I., and Filipowicz, W. 2010. The widespread regulation of microRNA biogenesis, function and decay. Nat. Rev. Genet. 11:597610

Lai-Kee-Him, J., Schellenberger, P., Dumas, C., Richard, E., Trapani, S., Komar, V., Demangeat, G., Ritzenthaler, C., and Bron, P. 2013. The backbone model of the Arabis mosaic virus reveals new insights into functional domains of Nepovirus capsid. J. Struct. Biol. 182:1-9.

Lanet, E., Delannoy, E., Sormani, R., Floris, M., Brodersen, P., Crete, P., Voinnet, O., and Robaglia, C. 2009. Biochemical Evidence for Translational Repression by Arabidopsis MicroRNAs. Plant Cell 21:17621768.

Lazzaretti, D., Tournier, I., and Izaurralde, E. 2009. The C-terminal domains of human TNRC6A, TNRC6B, and TNRC6C silence bound transcripts independently of Argonaute proteins. RNA 15:1059-1066.

Li, S., Liu, L., Zhuang, X., Yu, Y., Liu, X., Cui, X., Ji, L., Pan, Z., Cao, X., Mo, B., Zhang, F., Raikhel, N., Jiang, L., and Chen, X. 2013. MicroRNAs inhibit the translation of target mRNAs on the endoplasmic reticulum in Arabidopsis. Cell 153:562-574.

Liu, L., Grainger, J., Canizares, M. C., Angell, S. M., and Lomonossoff, G. P. 2004. Cowpea mosaic virus RNA-1 acts as an amplicon whose effects can be counteracted by a RNA-2-encoded suppressor of silencing. Virology 323:37-48.

Mallory, A., and Vaucheret, H. 2010. Form, function, and regulation of ARGONAUTE proteins. Plant Cell 22:3879-3889.

Morel, J. B., Godon, C., Mourrain, P., Beclin, C., Boutet, S., Feuerbach, F., Proux, F., and Vaucheret, H. 2002. Fertile hypomorphic ARGONAUTE (ago1) mutants impaired in post-transcriptional gene silencing and virus resistance. Plant Cell 14:629-639.

Omarov, R. T., Ciomperlik, J. J., and Scholthof, H. B. 2007. RNAi-associated ssRNA-specific ribonucleases in tombusvirus P19 mutant-infected plants and evidence for a discrete siRNA-containing effector complex. Proc. Natl. Acad. Sci. U.S.A. 104:1714-1719.

Pantaleo, V., Szittya, G., and Burgyan, J. 2007. Molecular bases of viral RNA targeting by viral small interfering RNA-programmed RISC. J. Virol. 81:3797-37806.

Parent, J. S., Martinez de Alba, A. E., and Vaucheret, H. 2012. The origin and effect of small RNA signaling in plants. Front. Plant Sci. 3:179.

Petersen, C. P., Bordeleau, M. E., Pelletier, J., and Sharp, P. A. 2006. Short RNAs repress translation after initiation in mammalian cells. Mol. Cell 21:533-542

Pfaff, J., and Meister, G. 2013. Argonaute and GW182 proteins: An effective alliance in gene silencing. Biochem. Soc. Trans. 41:855-860.

Pfaff, J., Hennig, J., Herzog, F., Aebersold, R., Sattler, M., Niessing, D. and Meister, G. 2013. Structural features of Argonaute-GW182 protein interactions. Proc. Natl. Acad. Sci. U.S.A. 110:E3770-3779.

Pumplin, N., and Voinnet, O. 2013. RNA silencing suppression by plant pathogens: Defence, counter-defence and counter-counter-defence. Nat. Rev. Microbiol. 11:745-760.
Qi, Y., He, X., Wang, X. J., Kohany, O., Jurka, J., and Hannon, G. J. 2006. Distinct catalytic and non-catalytic roles of ARGONAUTE4 in RNAdirected DNA methylation. Nature 443:1008-1012.

Qu, F., Ye, X., and Morris, T. J. 2008. Arabidopsis DRB4, AGO1, AGO7, and RDR6 participate in a DCL4-initiated antiviral RNA silencing pathway negatively regulated by DCL1. Proc. Natl. Acad. Sci. U.S.A 105:14732-14737.

Ratcliff, F., Harrison, B. D., and Baulcombe, D. C. 1997. A similarity between viral defense and gene silencing in plants. Science 276:15581560 .

Rogers, K., and Chen, X. 2013. Biogenesis, turnover, and mode of action of plant microRNAs. Plant Cell 25:2383-2399.

Rudel, S., Wang, Y., Lenobel, R., Korner, R., Hsiao, H. H., Urlaub, H., Patel, D., and Meister, G. 2011. Phosphorylation of human Argonaute proteins affects small RNA binding. Nucleic Acids Res. 39:2330-2343.

Sanfacon, H., Iwanami, T., Karasev, A., Van der Vlugt, R., Wellink, J. Wetzel, T., and Yoshikawa, N. 2011. Family Secoviridae. Pages 881899 in: Virus Taxonomy: Classification and Nomenclature of Viruses. Ninth Report of the International Committee on the Taxonomy of Viruses. A. M. Q. King, M. J. Adams, E. B. Carstens, and E. J. Lefkowitz, eds. Elseviers, San Diego, CA, U.S.A.

Schellenberger, P., Sauter, C., Lorber, B., Bron, P., Trapani, S., Bergdoll, M., Marmonier, A., Schmitt-Keichinger, C., Lemaire, O., Demangeat, G., and Ritzenthaler, C. 2011. Structural insights into viral determinants of nematode mediated Grapevine fanleaf virus transmission. PLoS Pathog. 7:e1002034. Published online.

Scholthof, H. B., Alvarado, V. Y., Vega-Arreguin, J. C., Ciomperlik, J., Odokonyero, D., Brosseau, C., Jaubert, M., Zamora, A., and Moffett, P. 2011. Identification of an ARGONAUTE for antiviral RNA silencing in Nicotiana benthamiana. Plant Physiol. 156:1548-1555.

Schott, G., Mari-Ordonez, A., Himber, C., Alioua, A., Voinnet, O., and Dunoyer, P. 2012. Differential effects of viral silencing suppressors on siRNA and miRNA loading support the existence of two distinct cellular pools of ARGONAUTE1. EMBO (Eur. Mol. Biol. Organ.) J. 31:2553-2565.

Schuck, J., Gursinsky, T., Pantaleo, V., Burgyan, J., and Behrens, S. E. 2013. AGO/RISC-mediated antiviral RNA silencing in a plant in vitro system. Nucleic Acids Res. 41:5090-5103.

Seitsonen, J. J., Susi, P., Lemmetty, A., and Butcher, S. J. 2008. Structure of the mite-transmitted blackcurrant reversion nepovirus using electron cryo-microscopy. Virology 378:162-168.

Sun, F., Xiang, Y., and Sanfacon, H. 2001. Homology-dependent resistance to tomato ringspot nepovirus in plants transformed with the VPg-protease coding region. Can. J. Plant Pathol. 23:292-299.

Szittya, G., Silhavy, D., Molnar, A., Havelda, Z., Lovas, A., Lakatos, L., Banfalvi, Z., and Burgyan, J. 2003. Low temperature inhibits RNA silencing-mediated defence by the control of siRNA generation. EMBO (Eur. Mol. Biol. Organ.) J. 22:633-640.

Takimoto, K., Wakiyama, M., and Yokoyama, S. 2009. Mammalian GW182 contains multiple Argonaute-binding sites and functions in microRNA-mediated translational repression. RNA 15:1078-1089.

Thermann, R., and Hentze, M. W. 2007. Drosophila miR2 induces pseudopolysomes and inhibits translation initiation. Nature 447:875-878.

Till, S., Lejeune, E., Thermann, R., Bortfeld, M., Hothorn, M., Enderle, D., Heinrich, C., Hentze, M. W., and Ladurner, A. G. 2007. A conserved motif in Argonaute-interacting proteins mediates functional interactions through the Argonaute PIWI domain. Nat. Struct. Mol. Biol. 14:897-903.

Tritschler, F., Huntzinger, E., and Izaurralde, E. 2010. Role of GW182 proteins and PABPC1 in the miRNA pathway: A sense of deja vu. Nat. Rev. Mol. Cell Biol. 11:379-384.

Varallyay, E., and Havelda, Z. 2013. Unrelated viral suppressors of RNA silencing mediate the control of ARGONAUTE1 level. Mol. Plant Pathol. 14:567-575.

Varallyay, E., Valoczi, A., Agyi, A., Burgyan, J., and Havelda, Z. 2010. Plant virus-mediated induction of miR168 is associated with repression of ARGONAUTE1 accumulation. EMBO (Eur. Mol. Biol. Organ.) J. 29:3507-3519.

Vargason, J. M., Szittya, G., Burgyan, J., and Tanaka Hall, T. M. 2003. Size selective recognition of siRNA by an RNA silencing suppressor. Cell 115:799-811.

Vaucheret, H. 2008. Plant ARGONAUTES. Trends Plant Sci. 13:350-358.

Vaucheret, H. 2009. AGO1 homeostasis involves differential production of 21-nt and 22-nt miR168 species by MIR168a and MIR168b. PLoS One 4:e6442. Published online.

Voinnet, O. 2009. Origin, biogenesis, and activity of plant microRNAs. Cell 136:669-687.

Voinnet, O., Rivas, S., Mestre, P., and Baulcombe, D. 2003. An enhanced transient expression system in plants based on suppression of gene silencing by the p19 protein of Tomato bushy stunt virus. Plant J. 33:949-956. 
Wang, X. B., Jovel, J., Udomporn, P., Wang, Y., Wu, Q., Li, W. X., Gasciolli, V., Vaucheret, H., and Ding, S. W. 2011. The 21-nucleotide, but not $22-$ nucleotide, viral secondary small interfering RNAs direct potent antiviral defense by two cooperative Argonautes in Arabidopsis thaliana. Plant Cell 23:1625-1638.

Yaegashi, H., Yamatsuta, T., Takahashi, T., Li, C., Isogai, M., Kobori, T., Ohki, S., and Yoshikawa, N. 2007. Characterization of virus-induced gene silencing in tobacco plants infected with apple latent spherical virus. Arch. Virol. 152:1839-1849.

Yang, L., Wu, G., and Poethig, R. S. 2012. Mutations in the GW-repeat protein SUO reveal a developmental function for microRNA-mediated translational repression in Arabidopsis. Proc. Natl. Acad. Sci. U.S.A. 109:315-320.

Ye, K., Malinina, L., and Patel, D. J. 2003. Recognition of small interfering RNA by a viral suppressor of RNA silencing. Nature 426:874-878.

Zeng, Y., Sankala, H., Zhang, X., and Graves, P. R. 2008. Phosphorylation of Argonaute 2 at serine-387 facilitates its localization to processing bodies. Biochem. J. 413:429-436.

Zhang, S. C., Zhang, G., Yang, L., Chisholm, J., and Sanfacon, H. 2005. Evidence that insertion of tomato ringspot nepovirus NTB-VPg protein in endoplasmic reticulum membranes is directed by two domains: A C-terminal transmembrane helix and an N-terminal amphipathic helix.
J. Virol. 79:11752-11765.

Zhang, X., Yuan, Y. R., Pei, Y., Lin, S. S., Tuschl, T., Patel, D. J., and Chua, N. H. 2006. Cucumber mosaic virus-encoded $2 \mathrm{~b}$ suppressor inhibits Arabidopsis Argonaute1 cleavage activity to counter plant defense. Genes Dev. 20:3255-3268.

Zhang, X., Singh, J., Li, D., and Qu, F. 2012. Temperature-dependent survival of Turnip crinkle virus-infected Arabidopsis plants relies on an RNA silencing-based defense that requires dcl2, AGO2, and HEN1. J. Virol. 86:6847-6854.

Zhu, H., Hu, F., Wang, R., Zhou, X., Sze, S. H., Liou, L. W., Barefoot, A., Dickman, M., and Zhang, X. 2011. Arabidopsis Argonaute10 specifically sequesters miR166/165 to regulate shoot apical meristem development. Cell 145:242-256.

Zielezinski, A., and Karlowski, W. M. 2011. Agos-A universal web tool for GW Argonaute-binding domain prediction. Bioinformatics 27:13181319.

\section{AUTHOR-RECOMMENDED INTERNET RESOURCE}

National Center for Biotechnology Information Cn3D program: www.ncbi.nlm.nih.gov/Structure/CN3D/cn3d.shtml 